\title{
POLITICAL SCIENCES
}

\section{Економічні теорії та державна регуляторна політика: механізми та інструменти реалізації}

\author{
М. О. Дурман, О. Л. Дурман \\ Херсонський національний технічний університет, м. Херсон, Україна \\ Corresponding author.E-mail: mykola.durman@gmail.com, ol.durman@gmail.com
}

Paper received 09.02.20; Accepted for publication 26.02.20.

\section{https://doi.org/10.31174/SEND-HS2020-223VIII37-11}

Анотація. В статті проводиться аналіз різних економічних теорій та можливість реалізації в них положень державної регуляторної політики (ДРП). Вказано, що більшість економічних теорій в тій чи іншій мірі допускають втручання держави в діяльність ринкової економіки через формування і реалізацію державної регуляторної політики. Механізми та інструменти ДРП в різних економічних теоріях можуть відрізнятися, проте саме за державою залишається право на вибір таких інструментів (крім лібертаріанства, яке обмежує таку можливість тільки дерегуляцією). Для України, на нашу думку, найбільш повно підходить неолібералізм, який поєднує в собі державне регулювання економічними процесами на всіх стадіях формування та дії ринкової економіки, використовуючи для цього інструменти, що відповідають не тільки потребам держави, але й потребам ринкової економіки.

Ключові слова: економічні теорії, регулювання ринкових відносин, державна регуляторна політика, механізми та інструменти державної регуляторної політики, неолібералізм, лібертаріанство.

Вступ. 3 обранням у 2019 році Президентом України Володимира Зеленського та «перезавантаження» влади (як законодавчої, так і виконавчої) в Україні почалися дискусії щодо того, яку теорію економічного розвитку може обрати нова українська влада. Суттєва підтримка українського соціуму, якою користувався Президент України, трансформувалося в можливість прийняття законодавчих та нормативно-правових актів, що поведуть країну в новому напрямку. Це досягається через підтримку президентських ініціатив Верховною Радою України, в якій президентська фракція має більшість, а також через формування відповідних політик соціально-економічного розвитку держави через ухвалення Програми діяльності Кабінету Міністрів України.

Проте, досі залишається невизначеним, яку економічну теорію буде використовувати нова влада як фундамент для покращення соціально-економічного розвитку країни та формування відповідних політик. Крім того, цікавим $є$ й відношення нової влади до державної регуляторної політики, а саме, і яких напрямках та у якій мірі буде відбуватися регулювання економіки за нових умов.

Короткий огляд публікацій по темі. Теоретикометодологічну основу різних видів економічних теорій, процеси формування державної політики, в тому числі й регуляторної, вивчали такі зарубіжні та вітчизняні вчені, як Л. Ергард [1], У. Митчел [2] і українські учені: В. Тертичка [3], О. Юлдашев [4], В. Ляшенко [5], І. Колупаєва [6] та інші.

Мета. Метою нашого дослідження є аналіз історичних та сучасних економічних теорій, а також вивчення можливості формування та реалізації державної регуляторної політики в тих чи інших економічних умовах.

Матеріали та методи. Організаційно-правові механізми формування та реалізації державної регуляторної політики в Україні ми вже розглядали в [7]. Так вказувалося, що управлінські процедури форму- вання державної регуляторної політики, відповідні механізми та інструменти покликані створювати умови, які дають змогу своєчасно реагувати на виклики i гарантують ефективність прийняття регуляторних управлінських рішень в ринкових економічних системах. Проте в ринкових економічних системах, що грунтуються на положеннях різних економічних теорій, набір цих механізмів та інструментів буде різний. Тому, насамперед, слід проаналізувати, які економічні теорії застосовувалися раніше чи застосовуються зараз для розвитку економік різних держав світу [8] i визначити, які механізми та інструменти можуть в них використовуватися для формування та реалізації державної регуляторної політики.

Теорія меркантилізму. Цю теорію пропагував А. Сміт у своїх ранніх роботах А. Сміт [9]. На першому етапі свого розвитку (XV - початок XVI ст.) меркантилізм набув форми монетаризму, який ідеалізував благородні метали і вважав їх єдиною формою багатства. Для другого етапу розвитку меркантилізму характерне те, що його прихильники обстоювали розширення зовнішньої торгівлі.

3 точки зору державної регуляторної політики можна вводити обмеження на вивезення грошей із країни, обмежувати імпорт та проводити інші аналогічні заходи. Обмеження на вивіз капіталу можуть проводитися адміністративним шляхом через встановлення умов центральним банком, а обмеження імпорту через встановлення високих ставок ввізних мит або високих акцизів на споживання імпортних товарів всередині країни.

Теорія вільного підприсмництва. Найвище іiі досягнення - пізніші праці А. Сміта та Д. Рікардо [10]. Ринок вони розглядали як саморегульовану систему, що найефективніше “невидимою рукою” розподіляє ресурси. Ринкова економіка за умов конкуренції забезпечує найкращий результат для усіх суб'єктів ринкових відносин - і для підприємців, що отримують ринок збуту з цінами, о гарантують прибуток, і для 
покупців, які отримують товари $з$ ефективним співвідношенням «ціна-якість», і для держави, яка зменшує свої адміністративні витрати на проведення регулювання, забезпечуючи при цьому високий рівень справедливості.

Принципи державної регуляторної політики у цьому випадку полягають у тому, що держава не втручається (або має мінімальний регуляторний вплив) у ці процеси, але мусить захистити конкуренцію від самих підприємців, не допускаючи її обмеження (через відповідне антимонопольне законодавство), а також створює загальні умови виробництва й забезпечує деякі загальні соціальні та державні послуги (освіту, дороги, зв'язок, безпека, кордони тощо).

Теорія економічної рівноваги. Представники неокласичної економічної теорії також висунули теорію загальної економічної рівноваги, згідно $з$ якою механізм вільної конкуренції (насамперед ринкового ціноутворення) забезпечує “справедливу винагороду кожного 3 факторів виробництва і повне використання економічних ресурсів". Це теорія А. Маршалла і А. Пігу [11]. Учені використовували поняття "ціна рівноваги”, обгрунтували поняття “еластичність попиту”, розвинули теорію ціни, що спирається на концепцію виробничих витрат.

3 точки зору цієї теорії, роль державної регуляторної політики полягає у перерозподілі доходів через активну податкову політику держави (прогресивна система податків, висока ставка податку на спадщину). Передбачається дві можливих форми державного втручання в економіку - через державний контроль над цінами та обсягами випуску продукції, а також через запровадження механізму прямих субсидій та «реверсних субсидій» (наприклад, у вигляді податків) як інструментів регулювання економіки. Також за цієї теорії не заперечується необхідність прямого втручання держави за умов посилення позицій монополій в економічному житті держави.

Теорія монетаризму (неоконсерватизму). Економічна теорія, згідно із якою грошова маса в обігу відіграє визначальну роль у формуванні економічної кон'юнктури та встановленні причинно-наслідкових зв'язків між зміною кількості грошей і величиною валового національного продукту, а також у розвитку виробництва. Її засновник - глава чиказької школи політичної економії М. Фрідмен [12]. Виходячи 3 кількісної теорії грошей, монетарної теорії економічного циклу, монетаризм розглядає роль грошової маси як визначальної ланки господарського механізму.

Роль державної регуляторної політики в цій теорії лежить в більшості випадків на монетарній політиці центрального банку країни (регулювання кількості грошей в обігу, встановлення відповідних облікових ставок, таргетування інфляціi). Проте в якості інструментів таргетування інфляції можуть виступати секвестр соціальних програм держави або зменшення витрат держави через приватизацію державних підприємств або скорочення штатів на державних підприємствах.

Кейнсіанство - у економічній теорії XX століття - одна з чільних макроекономічних шкіл, закладених Джоном Мейнардом Кейнсом. Започаткована працею
«Загальна теорія зайнятості, відсотків і грошей» [13]. Кейнсіанська теорія внесла фундаментальні зміни в економічну теорію, здійснивши принципово новий аналіз макроекономічних взаємозв'язків. Важливим $є$ те, що Кейнс переніс центр тяжкості з цінових і грошових факторів на виробництво, знайшовши механізми, які призводять до недосконалості ринкового саморегулювання, що визначає доцільність і необхідність державного регулювання економіки [14].

3 точки зору державної регуляторної політики доводилася необхідність активного втручання держави в макроекономічне функціонування ринкового господарства. Таке втручання здійснюється при проведенні такої макроекономічної політики уряду, яка втілюється в життя в залежності від стану економічної кон'юнктури. Також державне регулювання економічних процесів може бути пов'язане і з тим, що деякі послуги (витрати) можуть бути неефективними для окремих суб'єктів господарювання, але ефективними для суспільства у цілому. Як приклад, може виступати встановлення такого рівня тарифів на перевезення пасажирів залізничним транспортом, який нижче за собівартість, проте цей вид транспорту є єдиним або забезпечує велику частку транспортних перевезень. У цьому випадку держава може створювати умови для «перехресного» субсидіювання перевезень або забезпечити покриття різниці, що буде порушенням правил вільного ринку.

Теорія неолібералізму. Лібералізм - сукупність поглядів, основним змістом яких $є$ заперечення необхідності втручання держави в економічне життя й розуміння механізму самоорганізованого ринку як єдиного ефективного регулятора господарських процесів. Сучасні послідовники економічного лібералізму - неоліберали [15] - виступають за мінімальне втручання держави в економіку, за надання максимальної свободи підприємцям і торговцям. Ідеї неолібералізму були покладені в основу теорії соціально орієнтованого ринкового господарства, що проголошує необхідність вільної конкуренції, вільних цін тощо, гарантування державою цих умов і соціальну спрямованість їхнього розвитку.

У 80-90-их роках 20-ого століття неолібералізм став виступати за максимальну раціоналізацію процедур державного соціально-економічного регулювання. Крім того, у теорії неолібералізму спостерігалася орієнтація на своєрідне згортання процесів соціалізації лібералізму, що проявлялося у неприйнятті соціалдемократичних тенденцій [16]. На думку адептів неолібералізму, прагматизм соціальної політики має полягати в оптимізації стратегій відновлення „людського капіталу", але аж ніяк не в утвердженні примарної „держави загального добробуту”. Тобто, ресурси насамперед слід спрямовувати на перепідготовку робочої сили, але не на допомогу безробітним.

Неолібералами для державної регуляторної політики відводилася роль державного заохочення розвитку малого бізнесу, допомога технологічній перебудові традиційних галузей, встановлення податкових пільг для галузей, які $є$ конкурентоздатними на світовому ринку [17]. Наслідком такої політики повинна стати державна підтримка умов вільної конкуренції (формування дієвої системи антимонопольного законодав- 
ства), а також створення державою законодавчонормативної бази, що гарантує свободу особистої ініціативи в рамках ринкової економіки.

Теорія лібертаріанства. За лібертаріанським світоглядом, всі людські відносини мають базуватися на добровільних засадах; законом мають бути обмежені тільки такі дії, що силою примушують інших проти їхньої волі (вбивство, пограбування, згвалтування, викрадання за викуп та шахрайство) [18]. Як правило, більшість лібертаріанців виступають за право людини робити з собою та своєю власністю що завгодно, допоки це не заважає здійсненню аналогічного права іншими.

Класик лібертаріанства - Фрідріх Гаєк - мав Нобелівську премію з економіки і в своїй праці «Шлях до кріпацтва» вважав, що цей шлях починається 3 централізованого планування економікою, що пригнічує вільний ринок та завершується зникненням економічних та особистих свобод людини [19]. Принципово Гаєк не був проти державного втручання в економіку, але вважав, що мають існувати певні принципи, які б відокремлювали законне втручання від незаконного. До того ж, повинен виконуватися принцип справедливості - бізнесмен, який бажає, аби «держава злізла 3 його спини» не може, наприклад, вимагати протекціонізму від іноземної конкуренції

Проте і в цій економічній теорії є місце для втручання держави в економіку, в тому числі й з метою формування регуляторної політики. Наприклад, мінархісти (помірковане крило лібертаріанців) вважають за потрібне або необхідне існування податків, що їх стягує держава, єдиним завданням якої є захист життя, здоров'я та приватної власності громадян[20]. Також державна регуляторна політика у їх розумінні полягає в тотальній дерегуляції, тобто скасуванні всіх законів, норм і правил, що заважають вільному розвитку та існуванню особистості.

Результати і їх обговорення. В результаті проведеного аналізу можна сказати, що більшість економічних теорій в тій чи іншій мірі допускають втручання держави в діяльність ринку через формування і реалі- зацію державної регуляторної політики. Механізми та інструменти ДРП в різних економічних теоріях можуть відрізнятися, проте саме за державою залишається право на вибір таких інструментів (крім лібертаріанства, яке обмежує таку можливість тільки дерегуляцією).

Висновки. Яка ж економічна теорія з одного боку дає можливість розвивати економіку держави на достатньо високому рівні, не утискуючи при цьому суб'єктів господарювання, але залишаючи у держави важелі впливу на господарську діяльність цих суб'єктів через реалізацію положень державної регуляторної політики? Яка економічна теорія буде ефективною для України? Для України, на нашу думку, найбільш повно підходить неолібералізм, який поєднує в собі державне регулювання економічними процесами на всіх стадіях формування та дії ринкової економіки, використовуючи для цього інструменти, що відповідають не тільки потребам держави, але й потребам ринкової економіки. Так, активне державне регулювання економічних процесів відбувається на початковій стадії формування ринкової економіки (доки не почнуть діяти ринкові механізми самоорганізації). Після формування цих механізмів функції ДРП будуть відповідати за формування активної антимонопольної політики і за справедливий розподіл ресурсів держави. I, наостанок, державна регуляторна політика повинна створювати інституціональні механізми регулювання ринку людського капіталу, спрямованих, насамперед, не тільки на допомогу соціально незахищеним прошаркам населення, а й на стимулювання навчання i перепідготовки працівників, створенні нових робочих місць, в тому числі й за рахунок малого підприємництва та самозайнятості.

Проте нова влада України проголосила, що вона бере в основу економічного розвитку теорію лібертаріанства, тому подальші розвідки плануємо проводити саме у вивченні можливості використання різних механізмів ДРП у процесі економічного розвитку за цією теорією.
1. Історія економічних учень./Л. Я. Корнійчук, Н. О. Татаренко, А. М. Поручник та ін. - К.: КНЕУ, 1999. - 564 с

2. Mitchell W. Lecture Notes on Types of Economic Theory, 2 volumes, 1967

3. Тертичка В. Державна політика: аналіз та здійснення в Україні/В. Тертичка. - К.: Основи, 2002. - 750 с.

4. Юлдашев О.Х. Проблеми вдосконалення регуляторної політики. - К.: МАУП, 2005. - 364 с.

5. Ляшенко В. Регуляторна політика та удосконалення бізнес-середовища в Україні [Електронний ресурс]/Г. Толмачова, В. Ляшенко, В. Хахулін, О. Якубяк//Вісник економічної науки України. - 2013. - № 2. - С. 156-165. - Режим доступу: http://nbuv.gov.ua/UJRN/Venu_2013_2_39

6. Колупаєва I. В. Державна регуляторна політика: сутність та принципи формування [Електронний ресурс]/I. В. Колупаєва//Проблеми економіки. - 2013. - № 4. - С. 99-107. Режим http://nbuv.gov.ua/UJRN/Pekon_2013_4_14

7. Дурман М.О. Організаційно-правові механізми управлінської діяльності у формування державної регуляторної політики. Теорія та практика державного управління і місцевого самоврядування. 2019. № 2. URL:

\section{ЕРАТУРА}

http://nbuv.gov.ua/UJRN/Ttpdu_2019_2

8. Економічні теорії та їхні загальні положення. Сайт Україна - це ми! URL: https://we.org.ua/ekonomika/ekonomichniteoriyi-ta-yihni-zagalni-polozhennya/

9. Сміт А. Багатство народів. Дослідження про природу та причини добробуту націй (An Inquiry into the Nature and Causes of the Wealth of Nations)/пер. Олександра Васильєва. — К.: Наш Формат, 2018. - 722 с. — ISBN 978-6177552-14-6.

10. Рікардо Давид//Митна енциклопедія: у 2 т./І. Г. Бережнюк (відП. ред.) та ін.. - Хм.: ПП Мельник А. А., 2013. — Т. 2: $\mathrm{M}$ - Я. - С. 332. - 536 с. - ISBN 978-6177094-10-3.

11. Principles of Economics by Alfred Marshall. London: Macmillan and Co., Ltd. 1890 (англ.). URL: https://www.econlib.org/library/Marshall/marP.html

12. Фрідман, Мілтон Капіталізм і свобода/пер. 3 англ. Неля Рогачевська. — К.: Наш Формат, 2017. — 216 с. — ISBN 978-617-7279-77-7

13. John Maynard Keynes. General Theory of Employment, Interest and Money: Vol.7. URL: https://www.bookdepository.com/General-Theory- 
Employment-Interest-Money-Vol-7-John-MaynardKeynes/9780333009420

14. Мозговий О.М., Мусієць Б.Р. Державне регулювання товарно-грошових відносин: теоретичні основи. Економіка і організація управління •№ 4 (24) 2016. URL: jeou.donnu.edu.ualarticlel2927-5896-1-SM.pdf

15. Стедмен-Джоунз, Дэниел. Рождение неолиберальной политики. От Хайека и Фридмена до Рейгана и Тэтчер = Masters of the Universe: Hayek, Friedman, and the Birth of Neoliberal Politics. - Социум, Мысль, 2017. - 528 с. ISBN 978-5-906401-71-7, 978-5-244-01191-3, 978-0-69116101-3.

16. Куц Г. М. Неолібералізм: основні ідеї та інтерпретації. URL:

httpl|periodicals.karazin.ualpolitologylarticleldownload\
3223-Текст\%20статті-6589-1-10-20150702.pdf

17. Звеспер Дж. Лібералізм/Джон Звеспер//Енциклопедія політичної думки ; [пер. $з$ англ. Н. Лисюк, С. Альошкіної, І. Підлуської/редколег.: К. Сігов, В. Скуратівський, Л. Фінберг]. - К.: Дух і Літера, 2000. - 472 с. - С. 203-207.

18. Charles Murray.What It Means to $\mathrm{Be}$ a Libertarian, Broadway Books, 1997, ISBN 0553069284.

19. Friedrich A. Hayek. The condensed version of "The Road to Serfdom" as it appeared in the April 1945 edition of Reader's Digest. London: The Institute of Economic Affairs. 1999. ISBN 9780255365307

20. Ronald Hamowy, ред (2008). «Liberalism, Classical». The Encyclopedia of Libertarianism. Sage. ISBN 978-1-41296580-4.

\section{REFERENCES}

1. History of economic students./L. YA. Korniychuk, N. O. Tatarenko, A. M. Poruchnyk ta in. — K.: KNEU, 1999. - 564 $\mathrm{p}$

3. Tertichka V. State policy: analysis and implementation in Ukraine/V. Tertichka. - K.: Osnovy, 2002. - 750 p.

4. Yuldashev O. Problems of improvement of regulatory policy. - K.: MAUP, 2005. - 364 p.

5. Lyashenko V. Regulatory policy and improvement of the business environment in Ukraine//Visnyk ekonomichnoyi nauky Ukrayiny. - 2013. - № 2. - P. 156-165. - URL: http://nbuv.gov.ua/UJRN/Venu_2013_2_39

6. Kolupayeva I.V. State regulatory policy: the essence and principles of formation//Problemy ekonomiky. - 2013. - № 4. - P. 99-107.

URL: http://nbuv.gov.ua/UJRN/Pekon_2013_4_14

7. Durman M.O. Organizational and legal mechanisms of managerial activity in the formation of the state regulatory policy. The theory and practice of public administration and local self-government. 2019. № 2. URL: http://nbuv.gov.ua/UJRN/Ttpdu_2019_2

8. Economic theories and their general provisions. Site Ukraine is us! URL: https://we.org.ua/ekonomika/ekonomichniteoriyi-ta-yihni-zagalni-polozhennya/

9. Smith A. Wealth of nations. An Inquiry into the Nature and

Causes of the Wealth of Nations/trans. Alexander Vasilyev. K.: Nash Format, 2018. - 722 p. - ISBN 978-617-7552-14-6.

10. Ricardo David//Customs Encyclopedia: 2 vols./IG Berezhnyuk (ed.), Etc. - Khm.: PP Melnik A.A., 2013. - Vol. 2: M - Ya. - P. 332. - 536 p. - ISBN 978-617-7094-10-3.

12. Friedman, Milton Capitalism and freedom/trans. from English. Nelya Rogachevskaya. - K.: Nash Format, 2017. 216 p. - ISBN 978-617-7279-77-7

14. Mozhovyy O.M., Musiyets' B.R. State regulation of commodity-money relations: theoretical basis. Economics and Management • No. 4 (24) 2016. URL: jeou.donnu.edu.ua $\backslash$ article $\backslash 2927-5896-1-S M . p d f$

15. Steadman-Jones, Daniel. The birth of neoliberal politics. From Hayek and Friedman to Reagan and Thatcher $=$ Masters of the Universe: Hayek, Friedman, and the Birth of Neoliberal Politics. - Sotsyum, Mysl', 2017. - 528 p. - ISBN 978-5-906401-71-7, 978-5-244-01191-3, 978-0-691-16101-3.

16. Kuts G.M. Neoliberalism: basic ideas and interpretations. URL: http \ periodicals.karazin.ua \political science \article $\backslash$ download $\backslash 3223$-text\% 20art-6589-1-10-20150702.pdf

17. Zasper J. Liberalism/John Zasper//Encyclopedia of Political Thought; [trans. from English. N. Lysyuk, S. Alyoshkina, I. Podlusskaya/editor.: K. Sigov, V. Skuratovsky, L. Finberg]. K.: Dukh i Litera, 2000. - 472 p. - P. 203-207.

\section{Economic theories and state regulatory policy: mechanisms and tools for implementation \\ M. Durman, O. Durman}

Abstract. The article analyzes various economic theories and the possibility of implementing the provisions of the state regulatory policy (SRP). It is pointed out that most economic theories in one way or another allow state interference in the activities of a market economy through the formation and implementation of state regulatory policy. The mechanisms and instruments of the SRP may differ in different economic theories, but it is the state that has the right to choose such instruments (except libertarianism, which limits this possibility to deregulation only). In our opinion, neoliberalism is the best fit for Ukraine. It combines state regulation of economic processes at all stages of the formation and operation of a market economy, using for this purpose tools that meet not only the needs of the state, but also the needs of a market economy.

Keywords: economic theories, regulation of market relations, state regulatory policy, mechanisms and instruments of state regulatory policy, neoliberalism, libertarianism. 